\title{
PRIVATE CLOUD ARCHITECTURE \\ - ANALYSIS OF RELIABILITY
}

\section{ANALIZA NIEZAWODNOŚCI ARCHITEKTURY CHMURY PRYWATNEJ}

\author{
Paweł Stąpór, Dariusz Laskowski, Piotr Lubkowski \\ Wojskowa Akademia Techniczna im. J. Dąbrowskiego \\ Military University of Technology
}

\begin{abstract}
The multitude of cloud computing solutions available to users means that when choosing a specific variant of architecture, it is reasonable to consider the technical and functional capacity and security of the solution offered. The complexity of relations and relations in the CC architecture has been validated in conditions close to the real environment. The authors carried out a series of tests taking into account the heterogeneity of modern solutions in the field of interfaces, traffic control and offering services and user devices. The results were subjected to statistical analysis. The conclusions specify the basic observations and set the basic determinants (i.e. safety, quality, effectiveness, etc.) that are the basis for analytical considerations and their practical validation in the test bed.
\end{abstract}

Keywords: cloud computing, private cloud, reliability

Streszczenie: Mnogość rozwiazań chmur obliczeniowych dostępnych dla użytkowników sprawia, że przy wyborze konkretnego wariantu architektury zasadnym jest rozważenie zdatności technicznej $i$ funkcjonalnej oraz bezpieczeństwa oferowanego rozwiazania. Złożoność powiazań $i$ relacji $w$ architekturze Cloud Computing (CC) zostata poddana walidacji $w$ warunkach zbliżonych do rzeczywistego środowiska. Autorzy przeprowadzili szereg testów uwzględniających heterogeniczność współczesnych rozwiazań $w$ zakresie interfejsów, sterowania ruchem i oferowania ustug oraz urzadzeń użytkownika. Wyniki poddano analizie statystycznej. We wnioskach sprecyzowano zasadnicze spostrzeżenia $i$ określono determinanty bazowe (tj. bezpieczeństwo, jakość, efektywność, itp.) będace podstawa dla rozważan analitycznych i praktycznej ich walidacji $w$ test bed'ach.

Stowa kluczowe: niezawodność, sieć komputerowa, chmura prywatna. 
Private cloud architecture - analysis of reliability

Analiza niezawodności architektury chmury prywatnej

\section{PRIVATE CLOUD ARCHITECTURE - ANALYSIS OF RELIABILITY}

\section{Introduction}

Cloud Computing, as it can be observed in recent years, is becoming an increasingly popular solution in the field of IT. This is no longer a trend, but a well-developed technology, thanks to which companies can increase their efficiency and implement new projects. The IT industry expects that soon 4 out of 5 companies will use at least one cloud computing service, and $36 \%$ of all data will be stored in the cloud. It is anticipated that by 2020 more than $25 \%$ of all applications will have been available in the clouds. An access should be performed in accordance with the adopted criteria in the form of a specific set of system properties (i.e. in the form of potentiality, efficiency, quality, reliability and safety, etc.), defining the proper functioning of the system and its components in subjective or objective terms [3].

An important element to ensure high quality of services is to provide data transmission at specific time intervals and localization. This requirement is implemented by investing in modern hardware and software solutions from reputable equipment suppliers characterized by a high reliability index (MTBF Mean Time Between Failures, MTTR - Mean Time To Repair, readiness indicator [4], [5], [6]). Another, easier to implement solution is the use of hardware software redundancy preceded by a detailed analysis of the occurrence of events in the environment. This option does not require significant investments and is a flexible solution ensuring the desired technical and functional reliability [7], [8], [9], [10]. A particularly important requirement is that problems caused by the failure of one communication mode do not affect the loss of connection between remote nodes. Modern tele-information systems (STI) require reliable communication [11], [12] in the area of a network infrastructure. Additional security systems and new nodes absorb hardware resources, limiting network speed and computing power of devices. For dynamic network development with a minimum financial contribution, reliable traffic shaping models are needed that take into account several parameters. It is important that the parameters are selected dynamically and to minimize the load on the network elements. Improving network performance in terms of performance and ensuring the highest bandwidth and network stability is very important as it helps to ensure a high level of network reliability and extend the life of IT equipment. Legitimate steps in this regard include not only increased security, but also allow to reduce operating costs.

Important features characterizing modern technical devices include [13]: complexity of architecture, hardware and software. These features enforce a specific approach to the design process, selection of research methods and organization of operating system objects. The issue of measurement and evaluation criteria for the suitability and the relativity of the concept of ,state of suitability" of the analyzed system or device is particularly significant. 
Ensuring the security, reliability and quality of network services in relation to the network and application layer by means of control mechanisms discussed in [14] is another important issue. Therefore, the authors decided to propose CC architecture and analyze it for reliability and security (to a limited extent for data storage and transmission).

\section{Characteristics of Cloud Computing}

Cloud Computing is "a model that allows universal, convenient on-demand access to a common pool of configurable computing resources (e.g., networks, servers, mass storage, applications and services) that can be quickly delivered or shared with the minimum effort of the manager or supplier." [3]. Cloud computing should have several characteristics such as flexibility, the ability to combine resources, wide access to the network, self-service on demand. Three basic models of cloud computing implementation can be distinguished: public, private and hybrid being a combination of the two previous ones. In this article, the private cloud architecture will be analyzed, which is in fact its own IT structure providing IT services for a given number of users, protected by a common security system (firewall). The generalized cloud computing architecture (Figure 1) can be divided into three main areas.

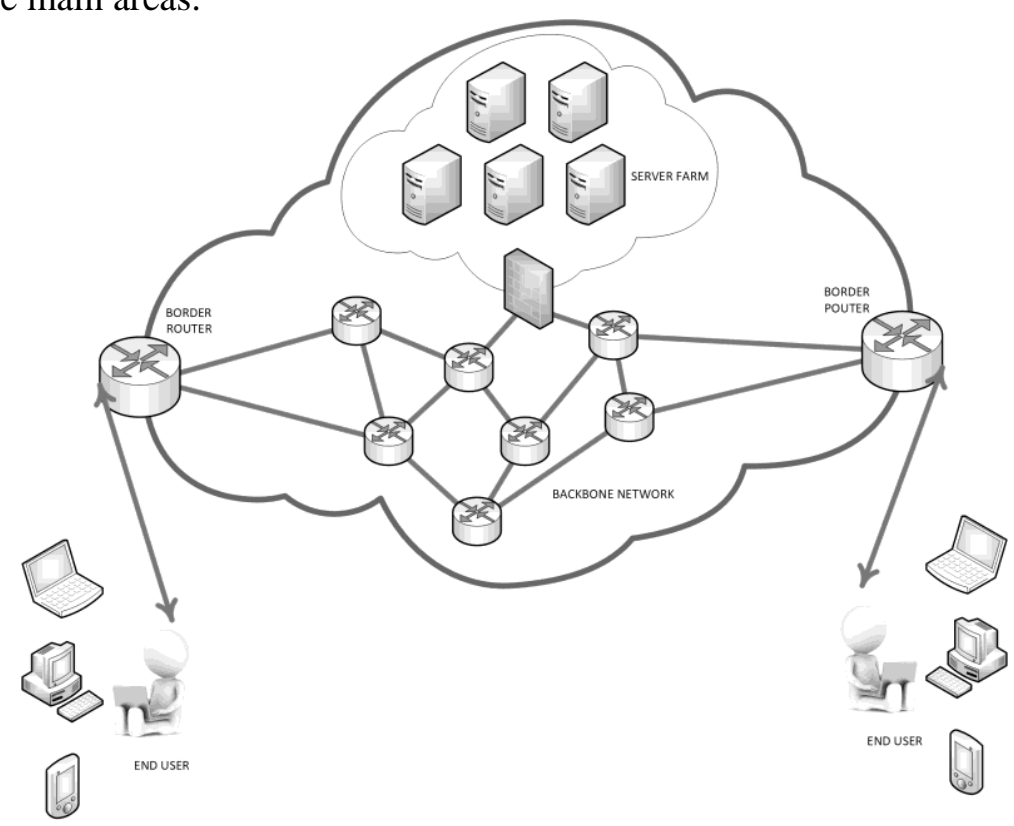

Fig. 1 Generalized cloud computing architecture [1].

The first one contains a server farm on which cloud management software is implemented. The second area relates to the core telecommunications network comprising routers, switches, and connections between devices. The third area is the area of an access to the network. 
Private cloud architecture - analysis of reliability

Analiza niezawodności architektury chmury prywatnej

It concerns, among others, ways of access to the network (wired, wireless), the type of terminal device (laptop, tablet, smartphone, etc.) and the system that is installed on it and the network location. The analysis carried out in the article refers to all of the above mentioned areas.

\section{Research model}

The architecture of the research model is presented in Fig. 2. The configuration of the tele-informatics network used public network devices, among others: Cisco 28XX and 29XX family routers, 24 port 3line switches of the Baseline 22XX family, Cisco Small Business WRVS4400 wireless routers and two Hewlett servers -Packard Proliant DL 360 generation 5 family with Ubuntu 14.04 LTS operating system and ownCloud and OpenSSL software. Confidentiality of communication was achieved through VPN tunnels using the SSLv3.0 protocol. This architecture provides the user with wired and radio access. On the client device (laptop) the operating system Windows 10 was installed, while on mobile devices (tablet, smartphone) the operating system Android. Wired communication with the network was carried out via the Gigabit Ethernet network interface, and wireless using the 802.11n interface. The network started routing using the OSPF protocol, while the devices were addressed using IPv4 addresses.

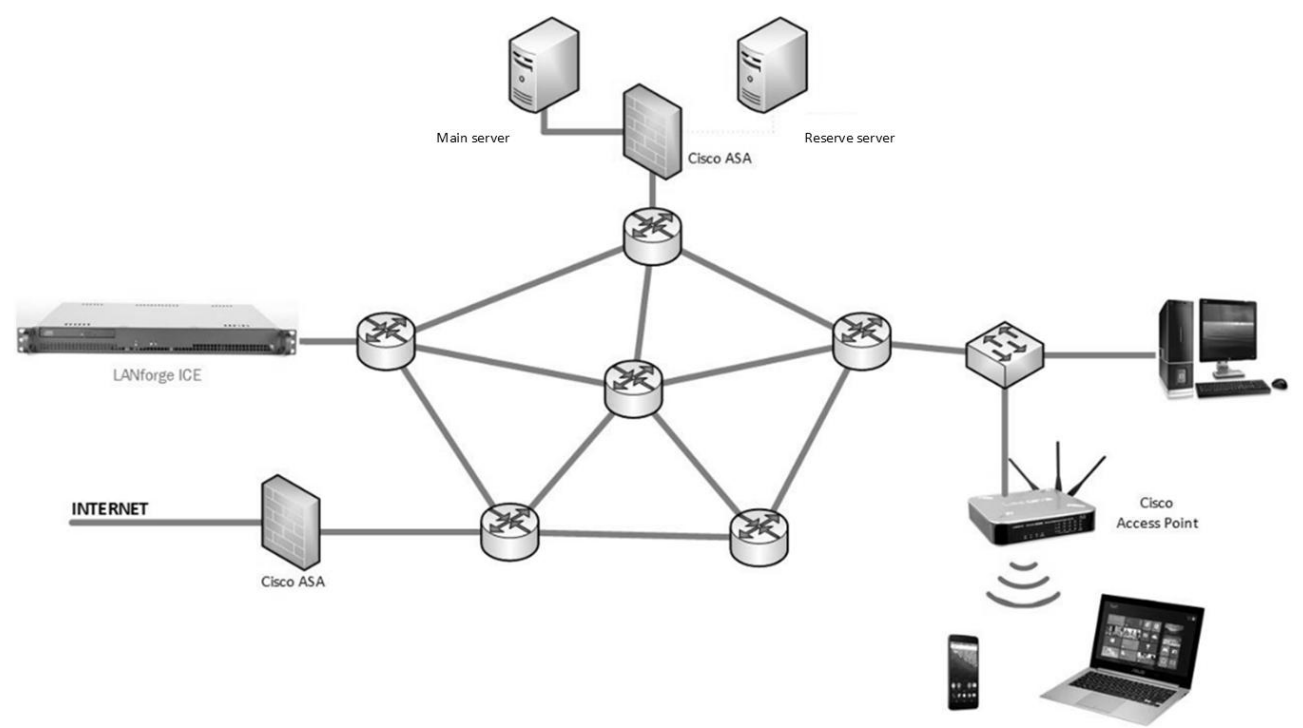

Fig. 2 Tested private cloud architecture.

The ownCloud application allows you to create a private cloud with an access to files (text documents, video, music and photos), contacts and calendars from anywhere via the Internet. An access to files is possible not only through the browser, but also through the WebDAV protocol (Web-based Distributed Authoring and Versioning). 
You can easily share files within the cloud between groups and individual users, as well as publicly with a password protected access and time of link availability. It is also possible to mount other resources and disk services, including FTP, DropBox, OneDrive or Google Drive.

In order to test the functioning of the cloud under load, performance tests were performed involving the inclusion of the LANforge ICE CT50 traffic generator in the network.

With regard to the presented model, the following tests were carried out:

- Time of access to the service locally and remotely via the Internet;

- Time to synchronize the service locally and remotely via the Internet;

- Analysis of hours of the largest network traffic (HLT) and determination of potential trajectories with CC implementation and without CC.

- Analysis of data transmission security using the Wireshark program.

\section{Test results and analysis}

On the basis of the research and the results obtained, a chart was prepared showing the access time to the service from three end-user devices in three different locations (Fig. 3). As you can see, the access time remains at the same level and ranges from 5 to 11 seconds. The access time depends mainly on the location and the way in which the user connects to the network. In the case when the user is within the range of the local network, then the access time is about 7-8 seconds. However, if the device connects to the target network remotely via the Internet, the access time is from 7.5 to more than 10.5 seconds. The longest access times were recorded for a connection using mobile Internet. This is due to the lower transmission speed compared to the data transmission speed available in the local network. The longer access time is also associated with the use of VPN connections that do not transport data at nominal speed, but slower due to data encryption.

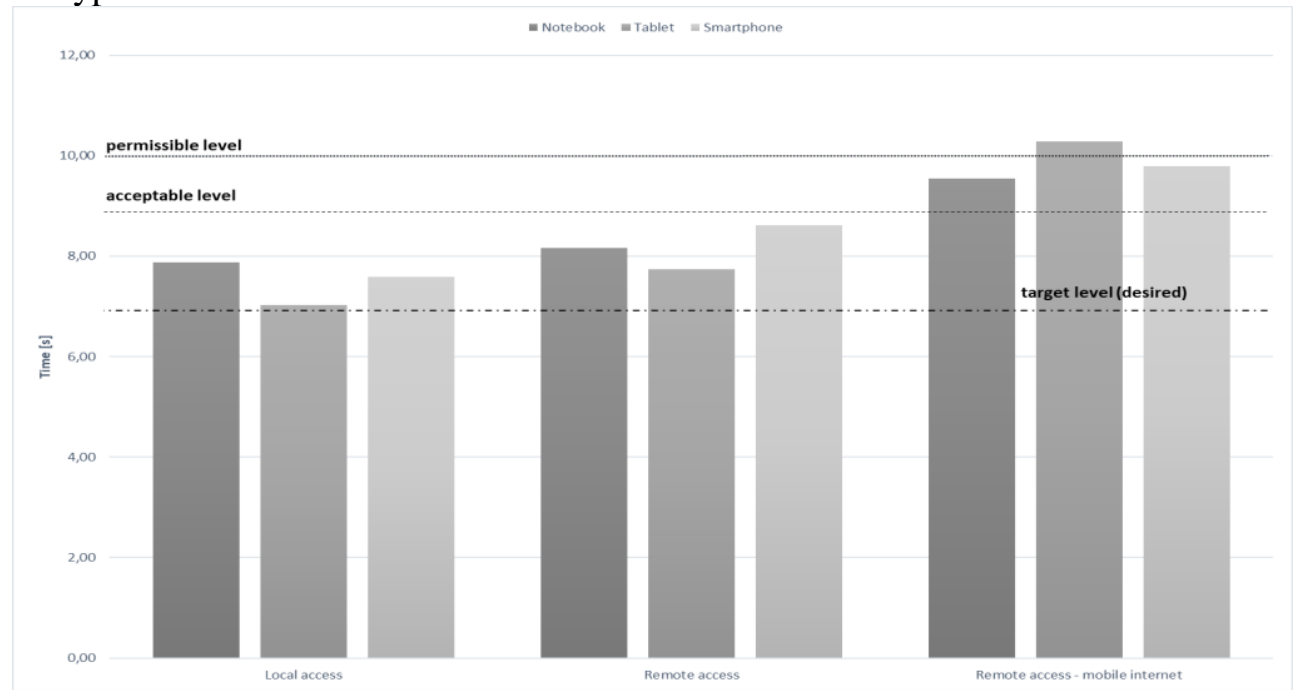

Fig. 3 Time access to the service from different locations. 
Private cloud architecture - analysis of reliability Analiza niezawodności architektury chmury prywatnej

In the next stage of research, the time of file synchronization between the server and the user's device was examined. The results presented in Fig. 4. It can be seen that the synchronization time, like the access time, depends on the network location. More favorable, "shorter" synchronization times are obtained at the local connection and they are about 6 seconds. However, with a remote connection, synchronizing the same files, we get up to half the time. It is related to m.in. with the distance the package has to travel from the sender to the recipient. However, despite the slight discrepancy, the acceptable and acceptable criterion is met in most cases.

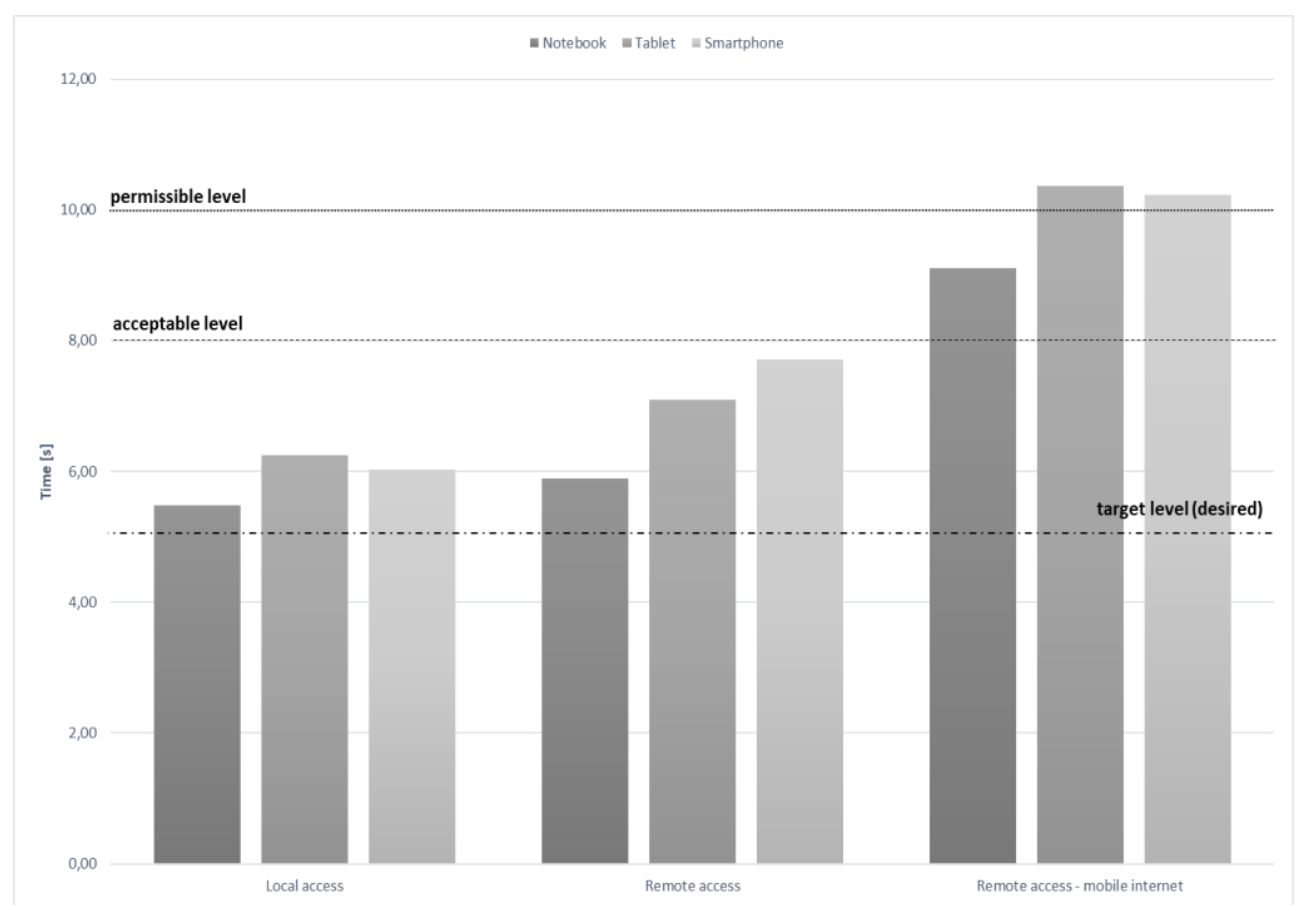

Fig. 4 Time to synchronize files from different locations.

The analysis of network traffic made it possible to gather information on the number of services provided for specific time intervals (Fig. 5). Based on the results, the time of the highest network traffic was determined, which is within the range of hours. $6: 00$ am to $6.00 \mathrm{pm}$.

Then, potential trajectories for 3 variants were determined for HLT: potentiality required, potential availability and potentiality without $\mathrm{CC}$ implementation. As can be seen in the graph below (Fig. 6), due to the implementation of a private cloud, it is possible to provide conditions for fulfilling each demand for a service - there is no understatement. It is also possible to run additional services. 
This is due to the fact that the mechanisms used in the computing cloud provide dynamic resource scaling, allocating the amount that is required by the user at a given time.

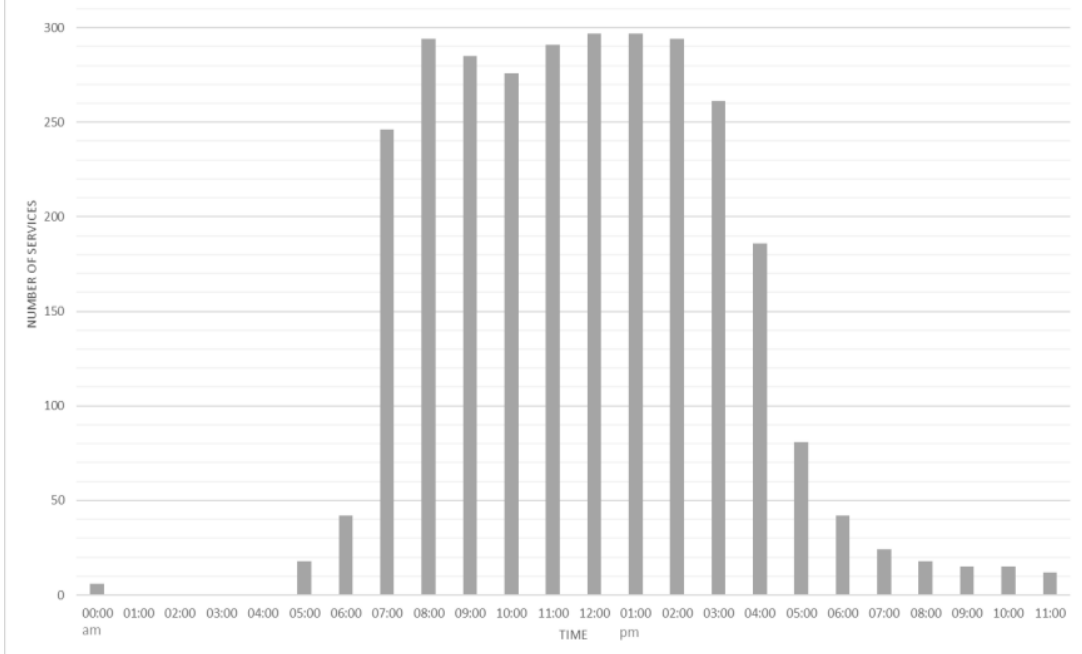

Fig. 5 Hours of the largest traffic (HLT).

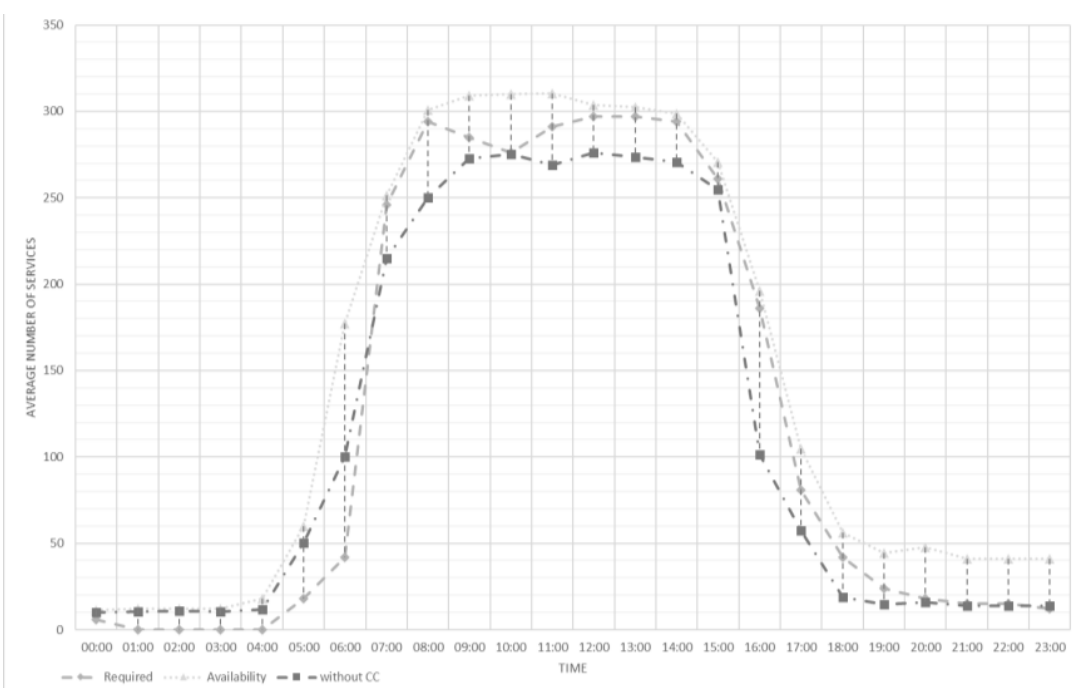

Fig. 6 Potential trajectories with CC and without CC.

Security analysis was conducted on the basis of packets intercepted using the Wireshark application (Fig. 7). Both the process of logging into the application and the synchronization of files between the client and the server were examined. Packets were captured using a wireless interface working in the $802.11 \mathrm{n}$ standard. 
Private cloud architecture - analysis of reliability

Analiza niezawodności architektury chmury prywatnej

\begin{tabular}{|c|c|c|c|c|}
\hline Tme & sarce & Destration & notosed & Lenges into \\
\hline 402.016200 & 192.169 .41 .8 & 289.70 .50 .100 & $\mathrm{reP}$ & 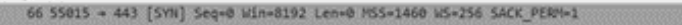 \\
\hline 412.016310 & 160.70 .59 .100 & 192.169 .41 .8 & TCP & 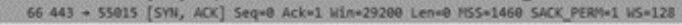 \\
\hline 422.020078 & 192.169 .41 .8 & 180.70 .50 .100 & TCP & 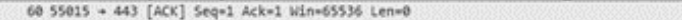 \\
\hline 442.051569 & 192.169 .41 .8 & 180.70 .50 .160 & TLSv1.2 & 571 Client Hello \\
\hline 45 2.051598 & 180.70 .50 .100 & 192.169 .41 .8 & TCP & Se 443 - sse1s [ACK] SeQ-1 Ack-518 uinese336 Len=0 \\
\hline $462.054 m$ & 180.79.5e.16e & 192.169 .41 .8 & TLSv1.2 & 1514 Server Hello, Certificate, Server Key Exchange \\
\hline 472.054005 & 180.70 .50 .100 & 192.169 .41 .8 & TLSvi.2 & 61 Server mello Done \\
\hline 482.059143 & 192.169 .41 .8 & 180.70 .50 .100 & TCP & 6055015 - $443[$ [ACK] Seg-518 ACk=1468 Win-65536 Lenete \\
\hline 492.077477 & 192.169 .41 .8 & 180.79 .59 .100 & TLSv1.2 & 150 Client Key Exchange, Change Cipher Spec, Hello Request, Hello Reguest \\
\hline 502.078168 & 180.70 .50 .100 & 292.169 .41 .8 & TLSv1.2 & 312 Ner Sessien Ticket, Change Cipher Spec, Encrypted mandshake Message \\
\hline \$1 2.086483 & 192.169 .41 .8 & 189.70 .50 .100 & TLSv1.2 & 793 Application Data \\
\hline 522.122700 & 160.70 .50 .100 & 192.169 .41 .8 & TCP & S4 463 - SSO1S [ACK] Seg-1726 Ack-1293 wine-31616 Lene0 \\
\hline 532.166747 & 180.70 .59 .100 & 192.169 .41 .8 & TLSv1.2 & 1514 Application Data, Application Dato \\
\hline 542.266757 & 180.70 .50 .100 & $192,169,41,8$ & TCP & 1514 [TCP segment of a reasseabled POU] \\
\hline 552.166515 & 180.70 .50 .100 & 192.169 .41 .8 & TLSv1.2 & 226 Application Data, Application Data \\
\hline 562.173379 & 192.169 .41 .8 & 180.70 .50 .100 & TCP & $6055015 \rightarrow 443[A C K]$ Seg-129] Ack=4646 winno65536 Len=0 \\
\hline 612.368604 & 192.163 .41 .8 & 180.70 .50 .100 & TLSv1.2 & 671 Application Data \\
\hline 622.308636 & 180.70 .50 .100 & 192.169 .41 .8 & & 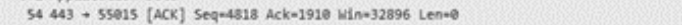 \\
\hline 662.309929 & 180.70 .50 .100 & 192.169 .41 .8 & TLSv1.2 & 1514 Application Data, Application Data \\
\hline
\end{tabular}

Fig. 7 Packets captured using the Wireshark program.

Service security analysis indicates that by using SSL and VPN connections, it is possible to ensure security at a certain level. Thanks to the authentication mechanism used, only authorized users have access to the resources collected in the cloud.

\section{Conclusions}

The architecture of cloud computing proposed by the authors was analyzed. The exemplary solution can be extended with additional architectural elements, thus increasing the range of possibilities offered by the computing cloud. This solution also allows connection to the public cloud. The proposed private cloud architecture is therefore a solution that guarantees confidentiality, integrity and authenticity of stored and transmitted data and high reliability. The conducted analysis indicates that the proposed solution is a reliable solution that enables the user to safely use cloud resources. However, the authors point out that the security and reliability of cloud computing depends largely on the awareness of users who are obliged to comply with the information security policy.

\section{References}

[1] Łubkowski, P., et al: Provision of the reliable video surveillance services in heterogeneous networks, Safety and Reliability: Methodology and Applications - Proceedings of the European Safety and Reliability Conference, ESREL 2014, CRT Press, A Balkema BOOK, 2015, pp. 883-888, Print ISBN: 978-1-138-02681-0, DOI: 10.1201/b17399-58.

[2] Łubkowski P., Laskowski D.: Selected Issues of Reliable Identification of Object in Transport Systems Using Video Monitoring Services, Communication in Computer and Information Science, Springer International Publishing AG / Springer Berlin Heidelberg, Switzerland, Volume 471, 2014, pp 59-68, ISSN 1865-0929, ISBN 978-3-662-45316-2 (Print), DOI 10.1007/978-3-662-45317-9_7, 2014. 
[3] P. Stąpór, D. Laskowski.: Concept of implementation cloud computing as a platform for telemetry systems, TST 2016, Ustroń [in publishing].

[4] Siergiejczyk M., Krzykowska K., Rosiński A. Reliability assessment of integrated airport surface surveillance system. In „Proceedings of the Tenth International Conference on Dependability and Complex Systems DepCoSRELCOMEX”, given as the monographic publishing series - „Advances in intelligent systems and computing", vol. 365. Springer 2015. pp. 435-443.

[5] Siergiejczyk M., Paś J., Rosiński A.: Issue of reliability-exploitation evaluation of electronic transport systems used in the railway environment with consideration of electromagnetic interference. IET Intelligent Transport Systems 2016, vol. 10, issue 9, 2016, pp. 587-593.

[6] Siergiejczyk M., Rosiński A., Krzykowska K.: Reliability assessment of supporting satellite system EGNOS. In: W. Zamojski, J. Mazurkiewicz, J. Sugier, T. Walkowiak, J. Kacprzyk (eds) New results in dependability and computer systems, given as the monographic publishing series - „Advances in intelligent and soft computing”, Vol. 224. Springer, 2013. pp. 353-364.

[7] Barlow R.E., Proschan F., Mathematical Theory of Reliability, John Wiley \& Sons, 1965.

[8] Misra K.B., Reliability Analysis and Prediction, Elsevier, New York, 1992.

[9] W.G. Ireson, Handbook of Reliability Engineering and management, McGraw-Hill, New York, 1996.

[10] Rychlicki M., Kasprzyk Z.: Increasing performance of SMS based information systems. In: „Proceedings of the Ninth International Conference Dependability and Complex Systems DepCoS-RELCOMEX", given as the monographic publishing series - „Advances in intelligent systems and computing", Vol. 286. Springer, 2014. pp. 373-382.

[11] Stawowy M., Dziula P.: Comparison of uncertainty multilayer models of impact of teleinformation devices reliability on information quality. In: "Proceedings of the European Safety and Reliability Conference ESREL 2015”, editors: L. Podofillini, B. Sudret, B. Stojadinovic, E. Zio, W. Kröger. CRC Press/Balkema, 2015. pp. 2685-2691.

[12]Bajda A., et al: Diagnostics the quality of data transfer in the management of crisis situation, Electrical Review 87(9A), pp. 72-78, 2011.

[13] Mell P., The NIST Definition of Cloud Computing, Recommendations of the National Institute of Standards and Technology, Special Publication 800-145. http://nvlpubs.nist.gov/nistpubs/Legacy/SP/nistspecialpublication800-145.pdf 
Private cloud architecture - analysis of reliability

Analiza niezawodności architektury chmury prywatnej

[14] Butlewski, M., Slawińska, M. 2014. Ergonomic method for the implementation of occupational safety systems, Occupational Safety and Hygiene II - Selected Extended and Revised Contributions from the International Symposium Occupational Safety and Hygiene, SHO 2014, pp. 621-626.

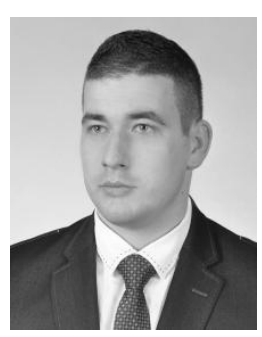

MSc. Pawel Stapór is a graduate and PhD student at the Faculty of Electronics at the Military University of Technology. He is interested in ICT networks, in particular mobile networks and new technological solutions. Mainly focused on the security, reliability and quality of access to network resources from different locations. (Share 33\%)

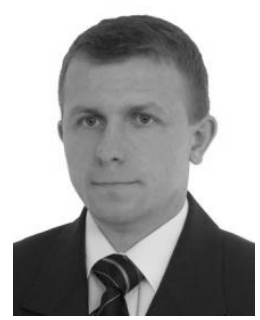

PhD. Eng. Dariusz Laskowski is a graduate of the Faculty of Electronics of the Military University of Technology. He deals with multi-aspect analysis of eye phenomena in heterogeneous services and networks offered by data transmission. It focuses on safety, maintenance, quality of life and technological security. (Share 33\%)

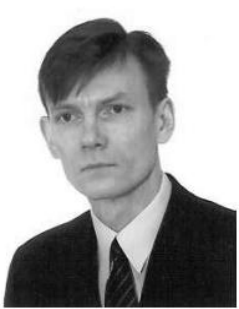

PhD. Piotr Lubkowski received the title of master engineer (1991) and doctor of technical sciences (2002) in the field of telecommunications and ICT in the Military University of Technology. Since 1992, he has been working at the Telecommunications Institute, Faculty of Electronics, Military University of Technology. It conducts research in the field of multimedia systems and services as well as QoS quality support in heterogeneous wireless ad hoc networks. (Share 33\%) 


\section{ANALIZA NIEZAWODNOŚCI ARCHITEKTURY CHMURY PRYWATNEJ}

\section{Wstęp}

Cloud Computing, jak można zaobserwować na przestrzeni ostatnich lat, staje się coraz bardziej popularnym zagadnieniem w dziedzinie IT. Nie jest to już trend, ale dobrze rozwinięta technologia, dzięki której firmy mogą zwiększyć swoją efektywność i realizować nowe projekty. Branża IT oczekuje, że wkrótce 4 na 5 firm skorzysta $\mathrm{z}$ co najmniej jednej usługi w chmurze obliczeniowej, a $36 \%$ wszystkich danych będzie przechowywanych w chmurze. Przewiduje się, że do 2020 r. ponad 25\% wszystkich wniosków będzie dostępnych w chmurach. Dostęp powinien być realizowany zgodnie z przyjętymi kryteriami w postaci określonego zestawu właściwości systemu (np. w postaci potencjalności, wydajności, jakości, niezawodności i bezpieczeństwa, itp.), określając prawidłowe funkcjonowanie systemu i jego komponentów w ujęciu subiektywnym lub obiektywnym [3].

Ważnym elementem zapewniającym wysoki poziom jakości usług jest zapewnienie transmisji danych w ściśle określonych przedziałach czasowych i lokalizacyjnych. Wymóg ten jest realizowany poprzez inwestycje $\mathrm{w}$ nowoczesne rozwiązania sprzętowe i softwarowe renomowanych dostawców sprzętu charakteryzujące się wysokim wskaźnikiem niezawodności (średni czas między awariami - MTBF, średni czas naprawy - MTTR, współczynnik gotowości - Kg [4], [5], [6]). Innym, łatwiejszym do wdrożenia rozwiązaniem jest wykorzystanie sprzętowej redundancji oprogramowania poprzedzonej szczegółową analizą możliwości wystąpienia zdarzeń w środowisku. Ten wariant nie wymaga znacznych inwestycji i jest elastycznym rozwiązaniem zapewniającym pożądaną niezawodność techniczną i funkcjonalną [7], [8], [9], [10].

Szczególnie istotnym wymaganie jest aby problemy spowodowane awarią jednego trybu komunikacji nie wpływały na utratę połączenia pomiędzy odległymi węzłami. Współczesne systemy teleinformatyczne (STI) wymagają niezawodnej komunikacji [11], [12] w obszarze infrastruktury sieciowej. Dodatkowe systemy bezpieczeństwa i nowe węzły absorbują zasoby sprzętowe, ograniczając prędkość sieci oraz moc obliczeniową urządzeń. Do dynamicznego rozwoju sieci przy minimalnym wkładzie finansowym potrzebne są niezawodne modele kształtujące ruch, które uwzględniają kilka parametrów. Ważne jest, aby parametry były wybierane dynamicznie i aby minimalizować obciążenie elementów sieci. Poprawienie działania sieci pod względem wydajności i zapewnienia najwyższej przepustowości i stabilności sieci jest bardzo ważne, ponieważ pomaga zapewnić wysoki poziom niezawodności sieci i przedłużyć żywotność sprzętu IT. Uzasadnione kroki w tym zakresie obejmują nie tylko wzrost bezpieczeństwa, ale także pozwalają na zmniejszenie kosztów operacyjnych. 
Private cloud architecture - analysis of reliability

Analiza niezawodności architektury chmury prywatnej

Ważnymi cechami charakteryzującymi nowoczesne urządzenia techniczne są m.in. [13]: złożoność architektury, sprzętu i oprogramowania. Te cechy wymuszaja konkretne podejście do procesu projektowania, wyboru metody badań i organizacji obiektów systemu operacyjnego. Na szczególną uwagę zasługuje kwestia pomiaru i oceny kryteriów przydatności oraz względności pojęcia "stanu zdatności" analizowanego systemu czy urządzenia. Zapewnienie bezpieczeństwa, niezawodności i jakości usług sieciowych $\mathrm{w}$ odniesieniu do sieci i warstwy aplikacji za pomocą mechanizmów kontrolnych dyskutowane w [14] jest kolejnym istotnym zagadnieniem. Dlatego też, autorzy zdecydowali się zaproponować architekturę CC i poddać ją analizie pod kątem niezawodności oraz bezpieczeństwa (w ograniczonym zakresie do przechowywania i przesyłania danych).

\section{Charakterystyka Cloud Computing}

Cloud computing jest to „model umożliwiający powszechny, wygodny dostęp na żądanie do wspólnej puli konfigurowalnych zasobów obliczeniowych (np. sieci, serwerów, pamięci masowych, aplikacji i usług), które mogą być szybko dostarczone lub udostępniane przy minimalnym wysiłku zarządzającego lub dostawcy"[3]. Chmura obliczeniowa powinna posiadać kilka cech charakterystycznych takich jak elastyczność, możliwość łączenia zasobów, szeroki dostęp do sieci, samoobsługa na żądanie. Można wyróżnić trzy podstawowe modele wdrożeniowe chmury obliczeniowej: publiczna, prywatna i hybrydowa będąca kombinacją dwóch poprzednich. W niniejszym artykule analizie zostanie poddana architektura chmury prywatnej, która jest de facto własną strukturą informatyczną dostarczającą usług IT dla określonej liczby użytkowników, chronionych wspólnym systemem zabezpieczeń (firewall). Uogólniona architektura chmury obliczeniowej (rys. 1) może zostać podzielona na trzy główne obszary

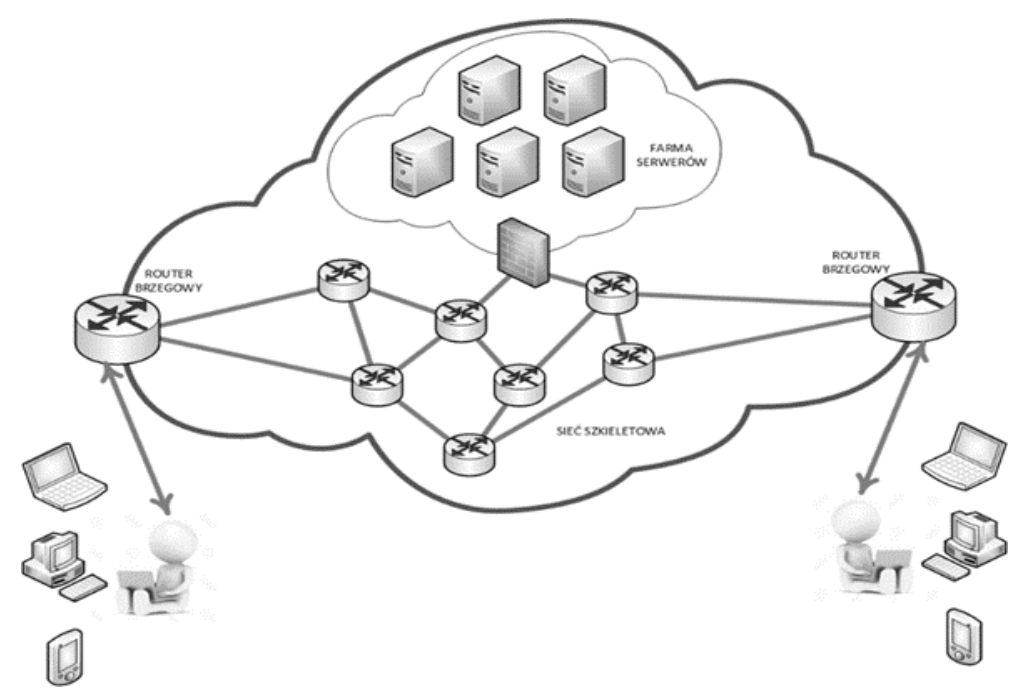

Rys. 1 Uogólniona architektura chmury obliczeniowej.[1] 
Pierwszy z nich zawiera farmę serwerów, na których zaimplementowane jest oprogramowanie zarządzające chmurą. Drugi obszar dotyczy szkieletowej sieci teleinformatycznej, zawierającej routery, przełączniki oraz połączenia między urządzeniami. Trzecim obszarem jest obszar dostępu do sieci. Dotyczy on m.in. sposobu dostępu do sieci (przewodowy, bezprzewodowy), rodzaju urządzenia końcowego (laptop, tablet, smartfon itp.) i systemu jaki jest na nim zainstalowany oraz lokalizacji sieciowej. Analiza przeprowadzona w artykule odnosi się do wszystkich wymienionych obszarów.

\section{Model badawczy}

Architektura modelu badawczego została przedstawiona na rysunku 2. Do konfiguracji badanej sieci teleinformatycznej użyto ogólnodostępne urządzenia sieciowe, m.in: routery Cisco rodziny $28 X X$ i $29 X X, 24$ portowe przełączniki 3COM rodziny Baseline 22XX, routery bezprzewodowe Cisco Small Business WRVS4400 i dwa serwery Hewlett-Packard rodziny Proliant DL 360 generation 5 z system operacyjnym Ubuntu 14.04 LTS oraz oprogramowaniem ownCloud i OpenSSL. Poufność komunikacja osiągnięto poprzez tunele VPN wykorzystujące protokół SSLv3.0. Architektura ta zapewnia użytkownikowi dostęp przewodowy i radiowy. Na urządzeniu klienta (laptop) zainstalowany został system operacyjny Windows 10, natomiast na urządzeniach mobilnych (tablet, smartfon) system operacyjny Android. Przewodowa komunikacja z siecią odbywała się przez interfejs sieciowy standardu Gigabit Ethernet, natomiast bezprzewodowa z wykorzystaniem interfejsu standardu $802.11 \mathrm{n}$. W sieci uruchomiono routing z wykorzystaniem protokołu OSPF, natomiast urządzenia były zaadresowane z wykorzystaniem adresów IPv4.

Aplikacja ownCloud umożliwia stworzenie prywatnej chmury $\mathrm{z}$ dostępem do plików (dokumentów tekstowych, wideo, muzyki i zdjęć), kontaktów i kalendarzy z każdego miejsca za pośrednictwem Internetu. Dostęp do plików możliwy jest nie tylko poprzez przeglądarkę, ale również przez protokół WebDAV (ang. Web-based Distributed Authoring and Versioning). W łatwy sposób można udostępnić pliki wewnątrz chmury pomiędzy grupami i pojedynczymi użytkownikami, jak również publicznie z zabezpieczonym hasłem dostępu oraz czasem dostępności linku. Możliwe jest również montowanie innych zasobów i usług dyskowych m.in. FTP, DropBox, OneDrive czy Google Drive.

W celu zbadania funkcjonowania chmury pod obciążeniem, wykonano badania wydajnościowe polegające na dołaczeniu do sieci generatora ruchu sieciowego LANforge ICE CT50. 
Private cloud architecture - analysis of reliability Analiza niezawodności architektury chmury prywatnej

W odniesieniu do przedstawionego modelu przeprowadzono następujące badania:

- Czas dostępu do usługi lokalnie i zdalnie poprzez Internet;

- Czas synchronizacji usługi lokalnie i zdalnie poprzez Internet;

- Analiza godzin największego ruchu (GNR) sieciowego i wyznaczenie trajektorii potencjałowych z implementacją CC oraz bez CC.

- Analiza bezpieczeństwa transmisji danych $\mathrm{z}$ wykorzystaniem programu Wireshark.

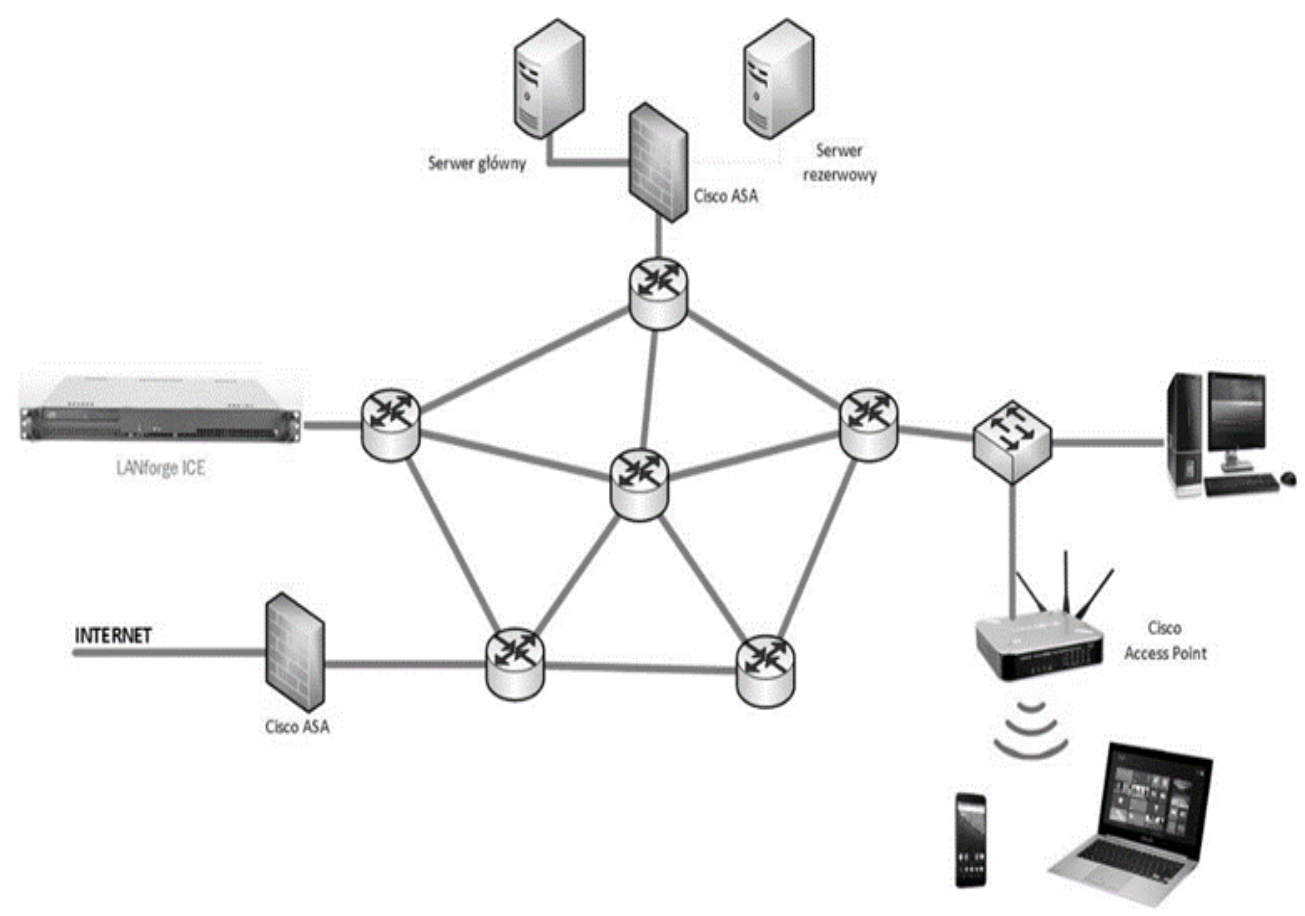

Rys. 2 Badana architektura chmury prywatnej.

\section{Wyniki badań i analiza}

$\mathrm{Na}$ podstawie przeprowadzonych badań i uzyskanych wyników sporządzono wykres przedstawiający czas dostępu do usługi z trzech urządzeń końcowych użytkownika końcowego w trzech różnych lokalizacjach (rys. 3). Jak można zauważyć czas dostępu utrzymuje się na tym samym poziomie i mieści się w przedziale od 5 do 11 sekund. W głównej mierze czas dostępu zależy od lokalizacji oraz sposobu w jaki użytkownik łączy się z siecią. W przypadku, gdy użytkownik znajduje się w zasięgu sieci lokalnej to wówczas czas dostępu wynosi około 7-8 sekund. Natomiast, jeżeli urządzenie łączy się z siecią docelową zdalnie 
poprzez Internet wtedy czas dostępu wynosi od 7,5 do ponad 10,5 sekund. Najdłuższe czasy dostępu odnotowano w przypadku połączenia $\mathrm{z}$ wykorzystaniem Internetu mobilnego. Spowodowane jest to mniejszą szybkością transmisji w porównaniu do prędkości transmisji danych dostępnej w sieci lokalnej.

Dłuższy czas dostępu jest związany także z zastosowaniem połączeń VPN, które nie transportują danych $\mathrm{z}$ nominalną prędkością, lecz wolniej ze względu na szyfrowanie danych.

W kolejnym etapie badań zbadano czas synchronizacji plików pomiędzy serwerem a urządzeniem użytkownika. Otrzymane wyniki prezentuje wykres (rys. 4). Można zauważyć, że czas synchronizacji, podobnie jak czas dostępu, zależy od lokalizacji sieciowej. Korzystniejsze, „krótsze” czasy synchronizacji otrzymujemy przy połączeniu lokalnym i wynoszą one około 6 sekund. Natomiast przy połączeniu zdalnym, synchronizując te same pliki uzyskujemy czas nawet o połowę dłuższy. Jest to związane m.in. z odległością jaką musi przebyć pakiet od nadawcy do odbiorcy. Jednak pomimo niewielkiej rozbieżności dla większości przypadków spełnione jest kryterium dopuszczalne i akceptowalne.

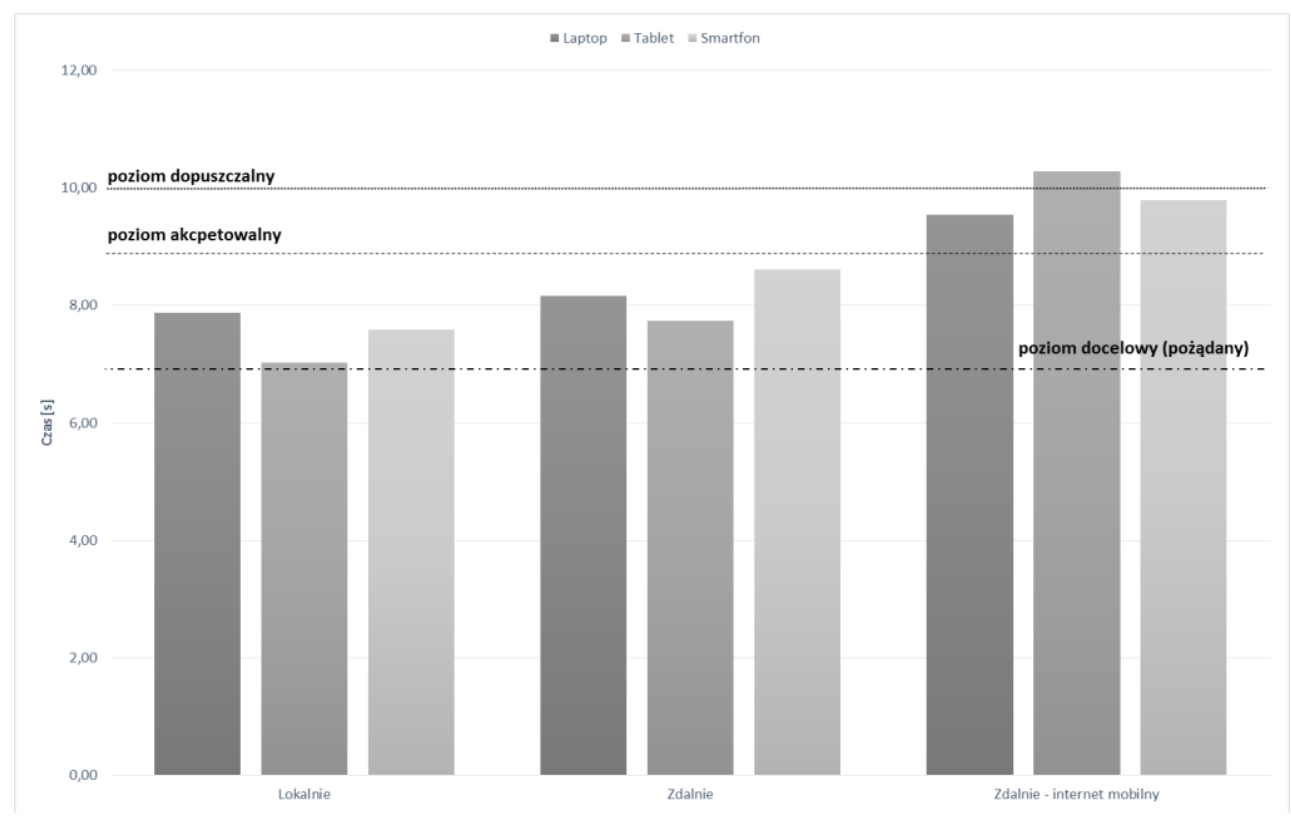

Rys. 3 Czas dostępu do ustugi z różnych lokalizacji.

Analiza ruchu sieciowego umożliwiła zebranie informacji o liczbie usług zrealizowanych określonych przedziałach czasowych (rys. 5). $\mathrm{Na}$ podstawie wyników określono godzinę największego ruchu sieciowego, która zawiera się w przedziale od godz. 06:00 do godz. 18:00. 
Private cloud architecture - analysis of reliability Analiza niezawodności architektury chmury prywatnej

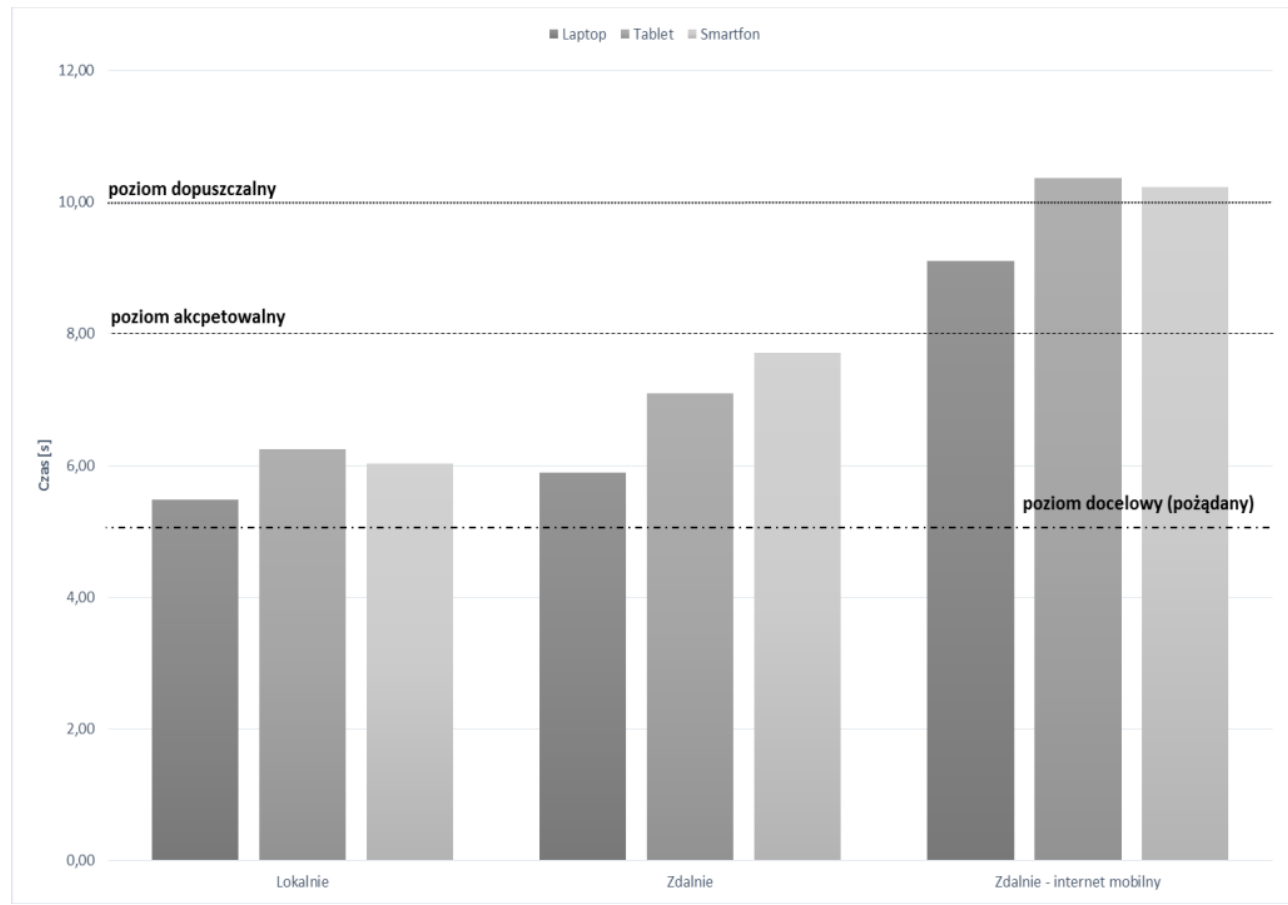

Rys. 4 Czas synchronizacji plików z różnych lokalizacji.

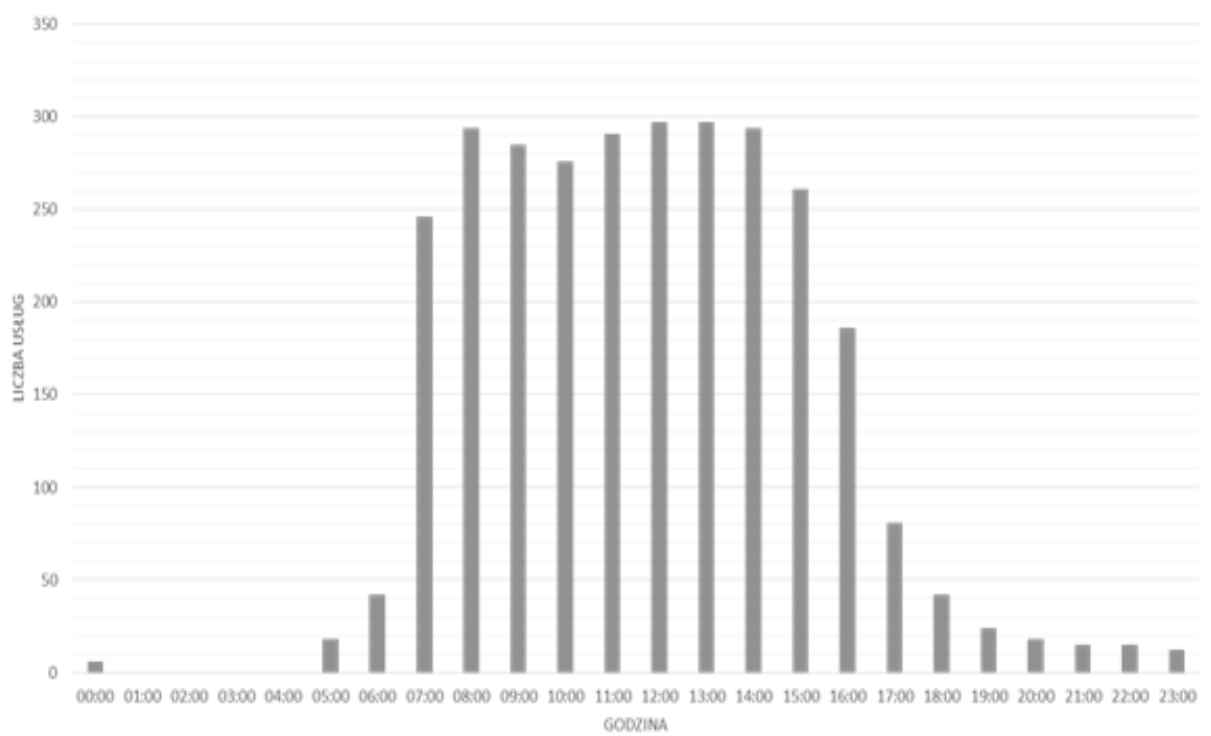

Rys. 5 Godziny największego ruchu (GNR). 
Następnie dla GNR wyznaczono trajektorie potencjałowe dla 3 wariantów: potencjalność wymagana, potencjalność dysponowana oraz potencjalność bez implementacji CC. Jak można zauważyć na poniższym wykresie (rys. 6) dzięki implementacji prywatnej chmury obliczeniowej możliwe jest zapewnienie warunków do zrealizowania każdego zapotrzebowania na usługę - nie ma niedomiaru potencjalności. Możliwe jest również uruchomienie dodatkowych usług. Wynika to $\mathrm{z}$ tego, że mechanizmy zastosowane w chmurze obliczeniowej zapewniają dynamiczne skalowanie zasobów, przydzielając taką ich ilość, która jest wymagana przez użytkownika w danej chwili czasu.

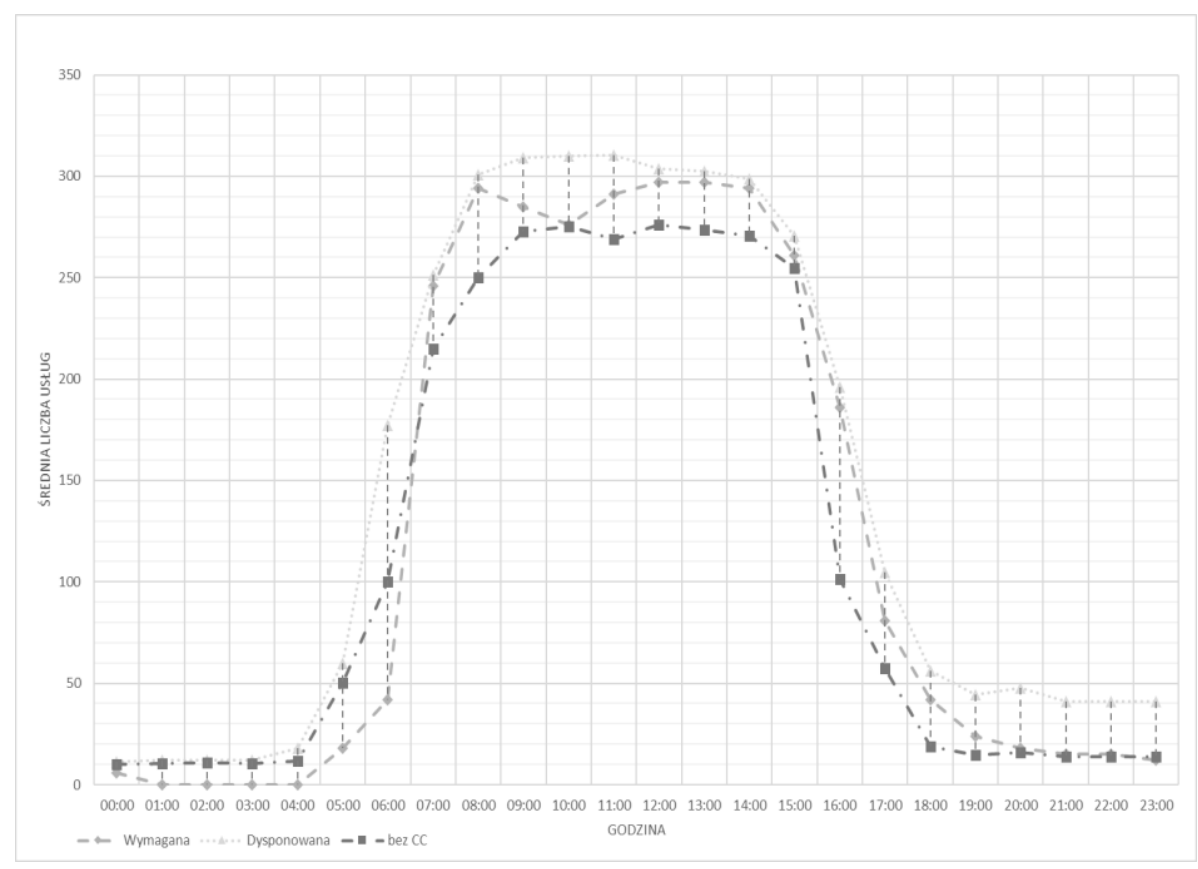

Rys. 6 Trajektorie potencjalowe z CC i bez CC.

Analizę bezpieczeństwa przeprowadzono na postawie pakietów przechwyconych z wykorzystaniem aplikacji Wireshark (rys. 7). Zbadano zarówno proces logowania do aplikacji jak i synchronizację plików pomiędzy klientem a serwerem. Pakiety były przechwytywane $\mathrm{z}$ wykorzystaniem interfejsu bezprzewodowego pracującego w standardzie $802.11 \mathrm{n}$.

Analiza zabezpieczeń usług wskazuje, że dzięki zastosowaniu protokołu SSL oraz połączeń VPN, możliwe jest zapewnienie bezpieczeństwa na określonym poziomie. Dzięki zastosowanemu mechanizmowi uwierzytelniania dostęp do zasobów gromadzonych w chmurze mają tylko uprawnieni użytkownicy. 
Private cloud architecture - analysis of reliability Analiza niezawodności architektury chmury prywatnej

\begin{tabular}{|c|c|c|c|c|}
\hline Time & Source & Destination & Protocol & Length Info \\
\hline 402.016290 & 192.169 .41 .8 & 180.70 .50 .100 & TCP & $6655015 \rightarrow 443$ [SWW] Seq=0 Win=8192 Len=0 MSS=1460 WS=256 SACK_ PERM=1 \\
\hline 412.016310 & 180.70 .50 .100 & 192.169.41.8 & TCP & $66443 \rightarrow 55015$ [SYW, ACK] Seq=0 ACK=1 Win=29200 Len=0 MSS=1460 SACK_PERM=1 WS=128 \\
\hline 422.020076 & 192.169.41.8 & 180.70 .50 .100 & TCP & $6055015 \rightarrow 443[A C K]$ Seq=1 Ack=1 Win=65536 Len=0 \\
\hline 442.051569 & 192.169.41.8 & 180.70.50.100 & TLSV1.2 & 571 Client Hello \\
\hline 452.051598 & 180.70.50.100 & 192.169.41.8 & TCP & $54443 \rightarrow 55015[A C K]$ Seq $=1$ Ack=518 Win=30336 Len $=0$ \\
\hline 462.054777 & 180.70.50.100 & 192.169 .41 .8 & TLSV1.2 & 1514 Server Hello, Certificate, Server Key Exchange \\
\hline 472.054805 & 180.70.50.100 & 192.169 .41 .8 & TLSV1.2 & 61 Server Hello Done \\
\hline 482.059143 & 192.169.41.8 & 180.70 .50 .100 & TCP & $6055015 \rightarrow 443[A C K]$ Seq=518 Ack=1468 Win=65536 Len=0 \\
\hline 492.077477 & 192.169 .41 .8 & 180.70 .50 .100 & TLSV1.2 & 180 Client Key Exchange, Change Cipher Spec, Hello Request, Hello Request \\
\hline 502.078168 & 180.70 .50 .100 & 192.169.41.8 & TLSV1.2 & 312 New Session Ticket, Change Cipher Spec, Encrypted Handshake Message \\
\hline 512.086483 & 192.169.41.8 & 180.70 .50 .100 & TLSV1.2 & 703 Application Data \\
\hline 522.122700 & 180.70.50.100 & 192.169.41.8 & TCP & $54443 \rightarrow 55015[A C K]$ Seq $=1726$ Ack=1293 Win=31616 Len=0 \\
\hline 532.166747 & 180.70 .50 .100 & 192.169 .41 .8 & TLSV1.2 & 1514 Application Data, Application Data \\
\hline 542.166757 & 180.70 .50 .100 & 192.169.41.8 & TCP & 1514 [TCP segment of a reassembled PDU] \\
\hline 552.166815 & 180.70 .50 .100 & 192.169.41.8 & TLSV1.2 & 226 Application Data, Application Data \\
\hline 562.173370 & 192.169 .41 .8 & 180.70 .50 .100 & TCP & $6055015 \rightarrow 443[$ [ACK] Seq=1293 Ack=4646 Win=65536 Len=0 \\
\hline 612.308604 & 192.169 .41 .8 & 180.70 .50 .100 & TLSV1.2 & 671 Application Data \\
\hline 622.308636 & 180.70.50.100 & 192.169.41.8 & TCP & $54443 \rightarrow 55015[A C K]$ Seq=4818 Ack=1910 Win=32896 Len=0 \\
\hline 662.309929 & 180.70 .50 .100 & 192.169 .41 .8 & TLSV1.2 & 1514 Application Data, Application Data \\
\hline
\end{tabular}

Rys. 7 Pakiety przechwycone za pomoca programu Wireshark.

\section{Wnioski}

Analizie poddano architekturę chmury obliczeniowej zaproponowaną przez autorów. Przykładowe rozwiązanie może być rozbudowywane o dodatkowe elementy architektury, zwiększając tym samym zakres możliwości oferowanych przez chmurę obliczeniową. Rozwiązanie to, także umożliwia połączenie z chmurą publiczną. Zaproponowana architektura chmury prywatnej jest zatem rozwiązaniem gwarantującym poufność, integralność i autentyczność przechowywanych i transmitowanych danych oraz wysoką niezawodność. Przeprowadzana analiza wskazuje, że zaproponowane rozwiązanie jest rozwiązaniem niezawodnym, umożliwiającym użytkownikowi bezpieczne korzystanie $\mathrm{z}$ zasobów chmury. Autorzy zwracają jednak uwagę, że bezpieczeństwo oraz niezawodność chmury obliczeniowej w dużej mierze zależy od świadomości użytkowników, którzy są obowiązani do przestrzegania polityki bezpieczeństwa informacji.

\section{Literatura}

[1] Łubkowski, P., et al: Provision of the reliable video surveillance services in heterogeneous networks, Safety and Reliability: Methodology and Applications - Proceedings of the European Safety and Reliability Conference, ESREL 2014, CRT Press, A Balkema BOOK, 2015, pp. 883-888, Print ISBN: 978-1-138-02681-0, DOI: 10.1201/b17399-58. 
[2] Łubkowski P., Laskowski D.: Selected Issues of Reliable Identification of Object in Transport Systems Using Video Monitoring Services, Communication in Computer and Information Science, Springer International Publishing AG / Springer Berlin Heidelberg, Switzerland, Volume 471, 2014, pp 59-68, ISSN 1865-0929, ISBN 978-3-662-45316-2 (Print), DOI 10.1007/978-3-662-45317-9_7, 2014.

[3] P. Stąpór, D. Laskowski.: Concept of implementation cloud computing as a platform for telemetry systems, TST 2016, Ustroń [in publishing].

[4] Siergiejczyk M., Krzykowska K., Rosiński A. Reliability assessment of integrated airport surface surveillance system. In „Proceedings of the Tenth International Conference on Dependability and Complex Systems DepCoSRELCOMEX”, given as the monographic publishing series - „Advances in intelligent systems and computing”, vol. 365. Springer 2015. pp. 435-443.

[5] Siergiejczyk M., Paś J., Rosiński A.: Issue of reliability-exploitation evaluation of electronic transport systems used in the railway environment with consideration of electromagnetic interference. IET Intelligent Transport Systems 2016, vol. 10, issue 9, 2016, pp. 587-593.

[6] Siergiejczyk M., Rosiński A., Krzykowska K.: Reliability assessment of supporting satellite system EGNOS. In: W. Zamojski, J. Mazurkiewicz, J. Sugier, T. Walkowiak, J. Kacprzyk (eds) New results in dependability and computer systems, given as the monographic publishing series - „Advances in intelligent and soft computing", Vol. 224. Springer, 2013. pp. 353-364.

[7] Barlow R.E., Proschan F., Mathematical Theory of Reliability, John Wiley \& Sons, 1965.

[8] Misra K.B., Reliability Analysis and Prediction, Elsevier, New York, 1992.

[9] W.G. Ireson, Handbook of Reliability Engineering and management, McGraw-Hill, New York, 1996.

[10] Rychlicki M., Kasprzyk Z.: Increasing performance of SMS based information systems. In: „Proceedings of the Ninth International Conference Dependability and Complex Systems DepCoS-RELCOMEX", given as the monographic publishing series - „Advances in intelligent systems and computing", Vol. 286. Springer, 2014. pp. 373-382.

[11] Stawowy M., Dziula P.: Comparison of uncertainty multilayer models of impact of teleinformation devices reliability on information quality. In: "Proceedings of the European Safety and Reliability Conference ESREL 2015”, editors: L. Podofillini, B. Sudret, B. Stojadinovic, E. Zio, W. Kröger. CRC Press/Balkema, 2015. pp. 2685-2691. 
Private cloud architecture - analysis of reliability

Analiza niezawodności architektury chmury prywatnej

[12] Bajda A., et al: Diagnostics the quality of data transfer in the management of crisis situation, Electrical Review 87(9A), pp. 72-78, 2011.

[13] Mell P., The NIST Definition of Cloud Computing, Recommendations of the National Institute of Standards and Technology, Special Publication 800-145. http://nvlpubs.nist.gov/nistpubs/Legacy/SP/nistspecialpublication800-145.pdf

[14] Butlewski, M., Sławińska, M. 2014. Ergonomic method for the implementation of occupational safety systems, Occupational Safety and Hygiene II - Selected Extended and Revised Contributions from the International Symposium Occupational Safety and Hygiene, SHO 2014, pp. 621-626.

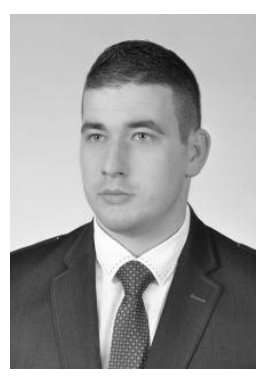

Mgr inż. Pawet Stapór jest absolwentem Wydziatu Elektroniki Wojskowej Akademii Technicznej. Interesuje sie sieciami teleinformatycznymi, w szczególności sieciami mobilnymi oraz nowymi rozwiązaniami technologicznymi. Głównie koncentruje się na bezpieczeństwie, niezawodności i jakości dostępu do zasobów sieciowych z różnych lokalizacji. (Udział 33\%)

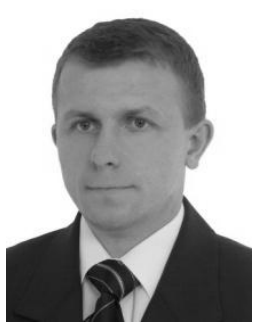

Dr hab. inz. Dariusz Laskowski jest absolwentem wydziału Elektroniki Wojskowej Akademii Technicznej, gdzie obecnie pracuje. Zajmuje się wieloaspektowa analiza zjawisk wplywajacych na prawidlowa realizacje ustug $w$ systemach isieciach heterogenicznych oferujacych transmisje danych. Koncentruje się na niezawodności, bezpieczeństwie, jakości oraz przetrwaniu obiektów technicznych pod katem ich praktycznego zastosowania w sieciach heterogenicznych. (Udziat 33\%)

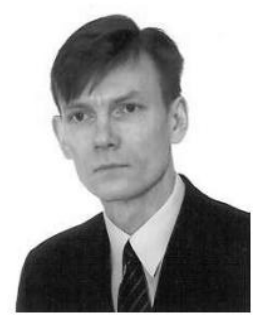

Dr inz. Piotr Lubkowski jest absolwentem Wojskowej Akademii Technicznej. Stopień doktora nauk technicznych uzyskat w 2002 roku $w$ dziedzinie telekomunikacji. Od 1992 roku pracuje w Instytucie Telekomunikacji na Wydziale Elektroniki Wojskowej Akademii Technicznej. Prowadzi badania z zakresu systemów $i$ ustug multimedialnych oraz wsparcia jakości $w$ bezprzewodowych sieciach heterogenicznych. (Udziat 33\%) 